\title{
末梢循環機能検查法としての容積脈波法の 基準化について
}

\author{
第 1 編 検査技術上の 2,3 の問題
}

\author{
元木 沢 交 昭 \\ 北海道大学医学部附属病院中央検査部 (主任 真下监明教授)
}

末梢の血液循環は心㖪のポンプ作用だけで規定され るものではなく，末梢血管系は心機能に対するものと は別個の神経性ならびに体液性の調節を受けているの で，条梢偱環機能を知ううとするには，心機能検査の ほが独自の検査が必要となる。

循環機能検査のうち, 心機能検査法としての心電図 法や心音図法はルーチンワーク化され, 日常診祭にお いては流れ作業的に行われているのに対し，末梢循環 機能検查法としての容積脈波法plethysmography は 日常検查法としてはまだ基準化されておらず，したが って実際の診潦にあたって容積脈波の記録が行われる こと法非常に少い。また容積脈波法が実施される場合 でも。検查者によって検查方法や検査成績の解釈など にかなりの相違がみられる状態である。

容禎脈波 plethysmogram 亿類似するものとして 動脈波 sphygmogram があるが，心電図法の確立以 前はこの動脈波の記録により不整脈の諺断が行われた ことがある。乙の場合の動脈波は，脈拍を触診によら ずに記録紙上に描記し，心拍りズムを客観的に知ろう としたもので，末梢血行状態の検查に役立てょうとし たものではなかった。したがって今日ではてのような 動脈波の記録はほとんど行われていない.

さて血液循環の生体における役割は，身体の各部に 動脈血を送り出し，静脈血を還流させることであるか ら, 未梢循噮機能検查の最終目標は, 器官や体肢の単 位組織量に対する血流量を知るとととなる。容積脈波 法は本来身体の 1 部の容積変化を記録する方法であり その容積変化はその局所の流入血液量と流出血液量に
よって決まるものであるから，容積脈波法により，局 所の血流変化をある程度推測できるてとになり,末梢 循環機能の診断に応用されうるものである。しかしな がら上記のように検查方法や成績の解釈などが，検査 者によってまちまちであるので, 容積脈波法が末梢偱 環機能検查法として広く普及するようになるにはての 検查法の基準化が必要である。

第 1 編ではそのような基準化のうち検査技術を基準 化するにあたって問題となる点, すなわち容積脈波計 における問題として容積脈波を記録する際の装置の時 定数をどのように設定すればよいか，また容積脈波計 と被㭘部を結合する際に生ずる問題として容積脈波導 出用ピックアップの装着圧をどのように選定すればよ いかについて娭討を行った。

\section{実 験 方 法}

実験は北大苪院中央検查部勤務の16～65才の健康男 子 8 名, 同じく $24 \sim 50$ 才の健康女子 5 名, 計 13 名につ いて行った。

容積脈波計は反射光電式を採用した，容積脈波導出 用のピックアップは市販のものを使用し，図1のよう な回路を組立て, 抵抗容量結合式 (CR) および直絬式 (D C)の両方式で導出できるようにした. 増幅と記録 は日本光電工業KK製多用途監視記録装置 RM-150型 で行い, 前置增幅器は主にRB-2を用い, 高感度の直 流増幅を必要とする場合はRDH一2を使用した。

実験は，被検者が実験前に過度の肉体的および精神 




図 1 容積脈波計の回路困

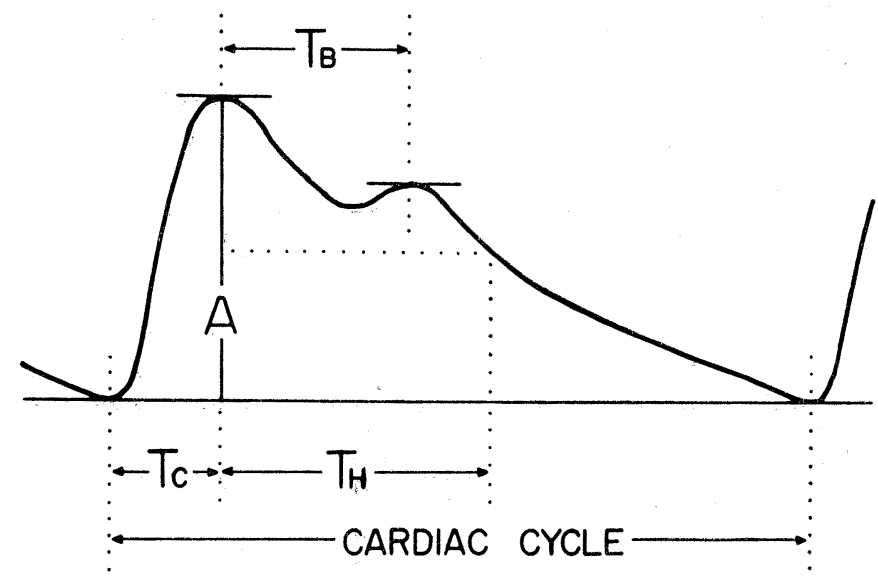

図2 容積脈波波形の計測項目

的興舊または疲学のないてとを破めてから行った。原 則として被検者は入室して診察用ベットに迎臥後10 20分を経てから実験を開始した，室温はに23〜25C 保ち、騒音はできるだけさけた，容積脈波の導出部位 は，原則として手指の場合は左右第 3 指末幯手掌側， 足趾の場合は左右第 1 趾足底側とし, 被検部はなるべ く心臟位になるようにした。

記録された容積脈波は，通常10個の波形について， 図 2 亿示すように初期隆起の振幅 $(\mathrm{A})$, 頂点時間 $\left(\mathrm{T}_{\mathrm{C}}\right)$, 基礎振動周期 $\left(\mathrm{T}_{\mathrm{B}}\right)$, および初期隆起の振幅の半減時 間 $\left(\mathrm{T}_{\mathrm{H}}\right), の 4$ 項目について計測し, 各々の平均值を 求めた。

\section{実 験 成 績}

1 時定数の大きさと波形の歪みとの関係

容積脈波は心電図や脳波に比心明らかに経過のゆる やかな波形を示すので，波形を問題にする場合には適 当な時定数を選ばなければならない，図 3 は右第 3 指 から導出した容積脈波を, 時定数を心(DC), $2 \mathrm{sec}$,

$0.3 \mathrm{sec} お よ ひ ゙ ~ 0.1 s e c の 4$ 段階にかえて同時記録した ものである。この図から，時定数0.3secと0.1secでは D C によ記録波形すなわち原波形が明らかに影響を 受けているととがわかる。DCと2 secによる波形の違 いは記録図上ではほとんど識別できないので波形の計 测を行い, 初期隆起の振幅, 頂点時閒, 基礎振動周期 
(392)

元木沢



图 3 時定数による波形の歪み

$0.5 \mathrm{sec}$

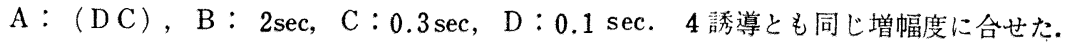

表 1

\begin{tabular}{|c|c|c|c|c|c|c|c|c|c|}
\hline \multirow[b]{2}{*}{ 榆被者 } & \multicolumn{2}{|c|}{$\begin{array}{c}\text { 振 幅 } \\
(\mathrm{mv})\end{array}$} & \multicolumn{2}{|c|}{$\begin{array}{c}\text { 頂点時間 } \\
\text { (sec) }\end{array}$} & \multicolumn{2}{|c|}{$\begin{array}{c}\text { 基礎振動周期 } \\
(\mathrm{sec})\end{array}$} & \multicolumn{2}{|c|}{$\begin{array}{c}\text { 半減時間 } \\
(\mathrm{sec})\end{array}$} & \multirow[t]{2}{*}{$\begin{array}{l}\text { 心藏周期 } \\
(\text { (sec) }\end{array}$} \\
\hline & D C & $2 \mathrm{sec}$ & D C & $2 \mathrm{sec}$ & $\mathrm{DC}$ & $2 \mathrm{sec}$ & D C & $2 \mathrm{sec}$ & \\
\hline 1 & 4.3 & 4.5 & 0.12 & 0.13 & 0.27 & 0.26 & 0.50 & 0.45 & 0.92 \\
\hline 2 & 4.2 & 4.6 & 0.13 & 0.13 & 0.27 & 0.27 & 0.47 & 0.43 & 0.98 \\
\hline 3 & 4.0 & 4.3 & 0.14 & 0.15 & 0.26 & 0.25 & 049 & 0.44 & 0.93 \\
\hline 4 & 4.3 & 4.5 & 0.13 & 0.13 & 026 & 0.26 & 0.48 & 0.43 & 0.97 \\
\hline 5 & 4.4 & 4.6 & 0.14 & 0.15 & 0.26 & 0.26 & 0.45 & 0.42 & 0.95 \\
\hline 6 & 4.6 & 4.8 & 0.12 & 0.14 & 0.27 & 0.27 & 0.48 & 0.44 & 0.95 \\
\hline 7 & 4.4 & 4.7 & 0.12 & 0.14 & 0.27 & 0.26 & 0.48 & 0.43 & 0.95 \\
\hline 8 & 4.6 & 4.8 & 0.13 & 0.14 & 0.27 & 0.26 & 0.50 & 0.47 & 0.98 \\
\hline 9 & 3.7 & 4.0 & 0.14 & 0.14 & 0.27 & 0.27 & 0.47 & 0.44 & 0.92 \\
\hline 10 & 4.4 & 4.6 & 0.13 & 0.13 & 0.27 & 0.26 & 0.48 & 0.45 & 0.93 \\
\hline M & 4.3 & 4.5 & 0.13 & 0.14 & 0.27 & 0.26 & 0.48 & 0.44 & 0.95 \\
\hline S D & 0.24 & 0.24 & 0.008 & 0.008 & 0.005 & 0.006 & 0.015 & 0.015 & 0.022 \\
\hline $\mathrm{CV}(\%)$ & 5.5 & 5.3 & 6.2 & 5.7 & 1.9 & 2.3 & 3.2 & 3.4 & 2.3 \\
\hline $\begin{array}{l}\mathrm{D} \\
\%\end{array}$ & & & $\begin{array}{l}0 . \\
1 .\end{array}$ & & $\begin{array}{l}0 . \\
1 .\end{array}$ & & 4. & & 100 \\
\hline
\end{tabular}

および初期隆起の振幅の半減時間の各項目について両 者を比較した，表 1 は，同一被検者につき，元木択 (1970)5) そしたがって容積脈波の振幅がほぼ恒常な時 期における波形10個についての成績である。各項目に つき平均值 $(\mathrm{M})$ と標準偏差 $(\mathrm{SD})$ を算出したが，はじ めに各項目の10個の波形における恒常性をみるために それぞれの変動係数 $(\mathrm{CV})=\mathrm{SD} / \mathrm{Mx} 100$ を求めたとて ろ振幅の変動係数が $5 \%$ 前後の場合は他の項目の変動 係数も非常に小さいてとがわかった. 次に頂点時間, 基 礎振動周期および初期隆起の振幅の半減時間の 3 項目
そついて時定数の影響をみるために，各項目につき時 定数 $く$ と $2 \sec$ の場合の平均值の差 (D) を求めたとて ろ, 頂点時間と基礎振動周期では $0.01 \mathrm{sec}$, 初期隆起


周期の平均值 $0.95 \mathrm{sec}$ 亿対する 100 分率で表わすと，そ れぞれ $1.05 \% ， 4.21 \%$ となった。すすなわち容積脈波記 録の時定数をのから $2 \mathrm{sec}$ 亿变えると，上記 3 項目の測 定值が 1 つの心臟周期の, 頂点時間 と基礎振動周期で は約 $1 \%$, 初期隆起の振幅の半隇時間では約 $4 \%$ 小さ くなるととがわかった。 
2 被検部の圧迫度と波形の歪子との関係

反射光電式容積脈波はピックアップ装着部の皮屬お よび皮下組織の各血管層の血流変化を記録しているも のであるから，ピックアップの装着圧を変えるとそれ ぞれの圧に対する各血管層の抵抗が違うので容積脈波 に変化の生ずることが予想される。 そこで右第 3 指尖 そピックアップを装着圧ほぼ零の状態でとりつけ，そ の上に小児血圧測定用マンシエットを巻き血圧計と接 続してピックアップの装着圧を変え, 各装着圧におけ る容積脈波の波形を比較した。図 4 はその1例である が，一般に上腕部の最低血圧の近傍で初期隆起および 重拍隆起とも最大振幅を示し, さらに装着圧を増すと



図4 被検部の圧迫による容積脈波の変形

\section{表 2}

\begin{tabular}{|c|c|c|c|c|}
\hline & 1 & 2 & 3 & 4 \\
\hline 被検者 & $\begin{array}{c}\text { 最高血圧 } \\
(\mathrm{mmHg})\end{array}$ & $\begin{array}{l}\text { 最低血压 } \\
(\mathrm{mmHg})\end{array}$ & $\begin{array}{l}\text { 最大振幅 } \\
\text { を示した } \\
\text { 装着压 } \\
\text { (mmHg) }\end{array}$ & $\begin{array}{l}2 \text { と } 3 の \text { 差 } \\
(\mathrm{mmHg})\end{array}$ \\
\hline 1 & 110 & 60 & 70 & +10 \\
\hline 2 & 106 & 50 & 60 & +10 \\
\hline 3 & 136 & 78 & 60 & -18 \\
\hline 4 & 110 & 66 & 60 & -6 \\
\hline 5 & 122 & 76 & 50 & -16 \\
\hline 6 & 125 & 94 & 80 & -14 \\
\hline 7 & 110 & 74 & 60 & -14 \\
\hline 8 & 44 & 64 & 50 & -14 \\
\hline 9 & 120 & 76 & 70 & -6 \\
\hline 10 & 120 & 80 & 80 & 0 \\
\hline
\end{tabular}

両振幅とも振幅を減ずるが, 重拍隆起の振幅減少率が 初期隆起のそれよりも大きく，つい僤醅性の波形と なり，最高血圧附近でそれもほとんど消失した，表 2 に示すように, 初期隆起の振幅が最大となる装着圧を 10名の被検者についてさらにくわしく観察すると，最 低血压よりも低い装着圧で最大振幅を示したもの7 名 最低血圧より高い装着圧で最大振幅を示したもの 2 名 残りの 1 名では最大振幅を示す压と最低血圧が同一の 值であった．いずれにせよ容積脈波の振幅が最大とな る装着压は50〜80 $\mathrm{mmHg}$ で，最低血圧との関係をみる

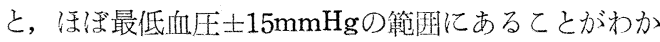
った.

\section{考按}

1 容積脈波導出方式の選択

容積脈波法はその原理により種々の方式が考案され ており，機械式(Winsor 1959) ${ }^{10)}$ ，光電式(Hertzman 1948)11)，インピーダンス式 (Nyboer 1959)6), 電気 容量式（䇾島 1956)4）お゙び電気抵抗式（Whiteney

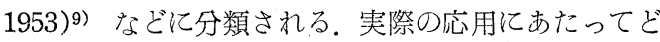
の方式を採用するかについてはそれぞれの目的によっ て異るが，池上 (1958)2）は機械式（水式），透過光 電式, 反射光電式および電気容量式, Matsumura (1968)3）は機械式（空気式と水式），透過光電式，反 射光電式およびィンピーダンス式の各方式により導出 記録された場合にはいずれの方式でもほぼ同一の波形 が得られたと報告している，以上により性能について は备方式の間にそれほど違いのないことがわかったが 末梢循環機能検査法として人体に応用するにあたって は，さらに使用が簡単で指尖以外にも広く利用できる こと，生体に与える物理化学的および機械的影響のも っとも少いてとを考慮すると, 反射光電式がもっとも 優れた方式であり，臨床検査に応用する場合にはこの 方式を採用するのがもっとも妥当と思われる。

\section{2 時定数の選定}

池上(1958)2) は CR 結合増幅器で容積脈波の基線を 記録すると，時定数の大きい場合はその変化は複雑に なり，時定数が小さくなると基線の変動はみられなく なりまた容積脈波の波形は変形して全く異ったもの になってしまうと述べている. 今回の実験では時定数 が0 3sec以下になると，一見して明らかな波形の变形 
(394)

元木沢

が珰められたが,波形の頂点時間,基礎振動周期および 初期隆起振幅の半減時間に着目して, 時定数 $\infty$ (DC) と $2 \sec$ による波形を比較したところ，前 2 者につい ては 1 心蔵周期の約 $1 \%$, 最後者については約 $4 \%$ の 違いが生じたが，いずれの項目もその変化は小さく， 結局時定数2sec以上で記録するとほぼ容積脈波の原波 形が得られることがわかった。したがって容積脈波の 波形を分析しようとする場合，必ずしも取扱いの不便 な直流増幅器を使用しなくとも，今回の実験で用いた ポリグラフ，万能型脳波計あるいは心電尌でその目的 をはたすととができるわけである。

3 容積脈波ピックアップの裁着圧の選定

㠻田(1958)8) は透過光電式で容積脈波を記録しなが ら被梚部を圧迫すると，圧迫の強さにしたがって谷積 脈波の波形が変化することを観察し，そのような変化 のおてる可能性をいくつか指摘している. Takagi と Nagasaka(1964)7）は容積脈波基線の変動パターンが 被検部の圧迫度により全く異ったものになることを示 し，皮䖉の血管層を浅在血管，小動脈および深部動脈 に分け, 浅在血管は30〜 $50 \mathrm{mmHg}$, 小動脈は $80 \mathrm{mmHg}$ で閉塞してしまうと推定している.一方個々の容積脈 波が最大振幅を示す装着压は $60 \mathrm{mmHg}$ であった。 こ のように容積脈波の振幅ならびに波形を比較する場合 には，容積脈波ピックアップの装着圧が重要な役割を なしていることがわかったが，実際の応用にあたって はどのように装着圧を選べばよいかについては, 容積 脈波の振幅が最大值を示す装着压を採用するのがもつ ともえいと思われる，それにより，被検者間または同 一被榆者についても検査のたびごとの比較がそのまま 行うととができるし，しかも上記Takagi とNagasaka (1964)7)によれば小動脈は閉塞されていないから皮膚 の血流を䮘い知ることができること，さらにその程度 の装着圧すなわち $50 \sim 80 \mathrm{mmHg}$ で圧迫した場合には 被检者に対してほとんど苦痛を与えないので，血管運 動反射のおこる可能性の少いことなど利点も多い. 以 後の榆査においては特別な場合をのぞき容積脈波の痕 幅が最大となるよう装着压を調整するようにした。

\section{総括}

容積脈波法を未梢循環機能検査法の一つとして確立 させるためには，その検査法の基準化が必要であるが
第 1 編では，その基準化のうち，検査技術における問 題について基礎的検討を行った。

1 容積脈波計および増幅記録器を含す総合時定数の 值により，容積脈波はそれぞれ変形を受けるととがわ かつたが, 時定数 $2 \mathrm{sec}$ 以上では原波形の変形は軽微 であり，実際の検査においてはほとんど問題のないて とがわかった。

2 容積脈波導出用のピックアップを指尖に装着する 際, その装着圧の大きさにより容積脈波の振幅も波形 も著明に変化することがわかったが，笑除查にあ たっては, 容積脈波の振幅が最大值となるように装着 压を選定するのが最良の方法であることが示された。

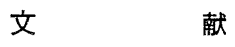

1) Hertzman, A. B. : Photoelectric plethysmograph of the skin. Med.Res., 1: 177-182, 1948.

2 ）池上芳男 : プレチスモグラフ法の比較的研究 呼吸之循環，6:881-890, 炤33.

3 ) Matsumura, M. : Comparative study on various methods of finger plethysmography. Tohoku J. exp. Med., $94: 337-346,1968$.

4 ) 筥島 高: 電気容量脈波計. 操坦道, 若林勲, 阪 本捷房編, 医学エレクトロニクス, 南山堂, 東京 周31，173-182.

5 ) 元木沢文昭 : 未佾循環機能検査法としての容積脈 波法の基準化について.

第 2 編 検査項目の選定と各項目の正常人にお ける成績. 北関東医, $20: 396-401$, 炤 45 .

6 ) Nyboer, J. : Electrical Impedance Plethysmography.

Charles C. Thomas; Springfield, I11., 1959.

7) Takagi, K. and Nagasaka, T. : Blood volume changes of various kinds of vessels in the human skin recorded by the reflection photoelectric plethysmograph. Jap. J. Physiol., 14:256-264, 1964.

8 ) 质田主一：光電容積脈波計減する基礎的検討. 日外会誌, $59: 275-293$, 炤33.

9) Whiteney. R. J. : The measurement of the volume changes in human limbs. J, 
Physiol., 121:1-27, 1953.

10) Winsor, T. : Peripheral Vascular Diseases:
An Objective Approach. Charles C.

Thomas; Springfjeld, I11., 1959.

\section{STANDARDIZATION OF PLETHYSMOGRAPHY FOR CLINICAL EXAMINATION OF PERIPHERAL BLOOD CIRCULATION}

\section{ON SOME TECHNICAL PROBLEMS}

FUMIAKI MOTOKIZAWA

Central Clinical Laboratory, Hokkaido Unjversity Hosdital, Sapporo, JAPAN

(Director: Prof. Keimei Mashimo)

Present address: Department of Physiology,

Gunma University School of Medicine, Maebashi, JAPAN

As a functional test of blood circulation, either electrocardiography or phonocardiography are essential in daily clinic. On the other hand, a plethysmography is not carried out so frequenfly, because either techniques or interpretation of results in the plethysmography differ with the examiner. In a series of the present experiment, it was planned to standardize the plethysmography as a method for examining a function of peripheral blood circulation. In the first section, experiments were performed to standardize the technique in the plethysmography.

1. In a series of the experiment, a reflexion photoelectric plethysmograph was used because it was easy to handle comparing with other methods of the plethysmograph.

2. A wave form of a plethysmogram was modified its shape due to a low frequency cut of the plethysmograph. If a time constant of the apparatus is over $2 \mathrm{sec}$, however, the change was insignificant.

3. An amplitude as well as a wave form of the plethysmogram was markedly changed due to compression a skin surface beneath the plethysmograph. It was discussed, therefore, that the plethysmograph must be attached to the skin with the pressure by which the plethysmogram showed its maximum amplitude. 